BIOMEDICAL AND BIOSOCIAL ANTHROPOLOGY
$\begin{gathered}\text { Official Journal of the International Academy } \\ \text { of Integrative Anthropology } \\ \text { journal homepage: http://bba-journal.com }\end{gathered}$

\title{
Features of the structural organization of the interlobular bile ducts under conditions of prolonged exposure to opioids in the experiment
}

Mateshuk-Vatseba L. R., Hirniak I. I.

Danylo Halytsky Lviv National Medical University, Lviv, Ukraine

\section{ARTICLE INFO}

Received: 7 June, 2019

Accepted: 12 July, 2019

UDC: $611.367-018.1: 615.212 .7]-08$

CORRESPONDING AUTHOR

e-mail: Ivatseba@gmail.com Mateshuk-Vatseba L. R.

\begin{abstract}
The article contains new information on the current problem of the influence of endoand exopathogenic factors on the structure of the digestive system. The purpose of the study was to establish the structural features of the interlobular bile ducts under the conditions of six weeks of exposure to nalbuphine in the experiment. The study was based on 30 white laboratory rats of male reproductive age. Histological sections of the liver were stained with hematoxylin and eosin according to conventional methods. The "Aver Media" computer system was used to photograph the micropreparations. The computer program ImageJ was used to measure the diameter of the lumen and the wall thickness of the interlobular bile duct. "Excel" and "Statistica" 6.0 software were used for statistical processing of the obtained digital data. The results of the study show that against the background of nalbuphine administration for six weeks there are morphological changes in the interlobular bile ducts of experimental animals, manifested by destructuring of the interlobular bile ducts, loss of their proper shape, expansion and unevenness of their lumens, deformation and thickening of the interstitial walls in 2-3 times, disorganization of cholangiocytes, thinning of the cell layer due to detachment of cholangiocytes, polymorphism of their nuclei, stratification, fragmentation of the lamina propria of the interlobular bile ducts, periductal edema, dilatation of interlobular portal tracts, "varicose" veins of the interlobular portal tracts, pronounced smooth muscle hyperplasia of the interlobular arteries, the presence of perivascular lymphocytic infiltrates. The data of the study can be used in practical medicine in the diagnosis and treatment of pathology of the bile ducts due to long-term use of opioids.

Keywords: interlobular bile ducts, microstructure, opioid, experiment.
\end{abstract}

\section{Introduction}

Pathology of the hepatobiliary system is a problem relevant to modern medicine [10,16, 22]. 388 people per 10 thousand population are registered with diseases of the biliary system, which is up to $50 \%$ of patients with pathology of the digestive system. In recent years, the importance of drug-induced lesions of the liver and intrahepatic bile ducts has increased significantly $[7,13,14,28]$. The negative effect of the use of drugs today creates not only a serious medical and social, but also economic problem. In order to obtain an analgesic effect in patients with acute cholecystitis or acute cholangitis, opioids are used [25], in particular morphine [6]. The influence of opioids on the morphological state of the digestive system is devoted to single works $[2-4,12,18$, 23]. It has been established that in cholestatic liver diseases the concentration of endogenous opioid peptides increases in blood plasma, which indicates a close functional relationship between the hepatobiliary and opioid systems and the role of the latter in the development of pathology [15]. The rapid progressive destruction of intrahepatic bile ducts associated with the use of narcotic agents [17], the effect of the opioid ketamine on the bile ducts [1, 24]. However, many issues of this problem still remain unresolved and require additions and clarifications. Modeling of a pathology on experimental animals allows a deeper study of morphological and functional changes in the body $[5,27]$.

The above determined the purpose of our study - to establish the structural features of the interlobular bile ducts under conditions of six weeks of exposure to nalbuphine in the experiment. 


\section{Materials and methods}

The studies were performed on 30 adult white male rats, aged 3.5-5.0 months and weighing 180-200 g.

Experimental animals were divided into 3 series: in the first series ( 7 rats) the structure of interlobular bile ducts of white rats after 2 weeks of nalbuphine administration was studied, in 2 series of experiments (7 rats) changes in angioarchitectonics and microstructure of interlobular bile ducts were studied after 4 weeks, in 3 series of experiments ( 7 rats) the reorganization of the bloodstream and the microstructure of the interlobular bile ducts of experimental animals after 6 weeks of nalbuphine administration. The control was 9 white male rats, which were injected with $0.9 \%$ sodium chloride solution.

Administration of nalbuphine was performed intramuscularly according to the following scheme: I week $8 \mathrm{mg} / \mathrm{kg}$, II week - $15 \mathrm{mg} / \mathrm{kg}$, III week - $20 \mathrm{mg} / \mathrm{kg}$, IV week - 25 $\mathrm{mg} / \mathrm{kg}, \mathrm{V}$ week - $30 \mathrm{mg} / \mathrm{kg}$, week VI - $35 \mathrm{mg} / \mathrm{kg}$ [20].

All animals were kept in the vivarium of Lviv National Medical University named after Danylo Halytsky, experiments were conducted in accordance with the provisions of the European Convention for the Protection of Vertebrate Animals Used for Experimental and Other Scientific Purposes (Strasbourg, 1986), Council Directive 86/609/EEC (1986), Law of Ukraine № 3447 - IV "On protection of animals from cruel treatment", general ethical principles of animal experiments, approved by the First National Congress of Ukraine on Bioethics (2001).

The study material is represented by histological preparations of the liver of white rats. For histological examination, sections were stained with hematoxylin and eosin. The preparations were studied and photographed at microscope magnifications $\times 400$ and $\times 1000$. The "Aver Media" computer system was used to photograph the micropreparations.

The computer program ImageJ was used to measure the diameter of the lumen and the wall thickness of the interlobular bile duct. "Excel" and "Statistica" 6.0 software were used for statistical processing of the obtained digital data.

\section{Results}

After 2 weeks of administration of nalbuphine to white rats, the structural organization of the interlobular bile ducts of experimental animals, as well as control animals is preferably preserved. The interlobular bile ducts are clearly contoured, their lumen is clearly visible, the ducts are surrounded by connective tissue (preferably one bile duct per portal tract). The wall of the interlobular bile ducts is lined with a single layer of cubic fringed epitheliocytes cholangiocytes, which are adjacent to its own plate, formed by a thin layer of connective tissue (Fig. 1). Cholangiocytes had a typical structure, distinct apical, basal and lateral surfaces (the latter adjacent to each other), a large, oval nucleus with clear contours, located in the center of the cell. Morphometric analysis of histological specimens revealed

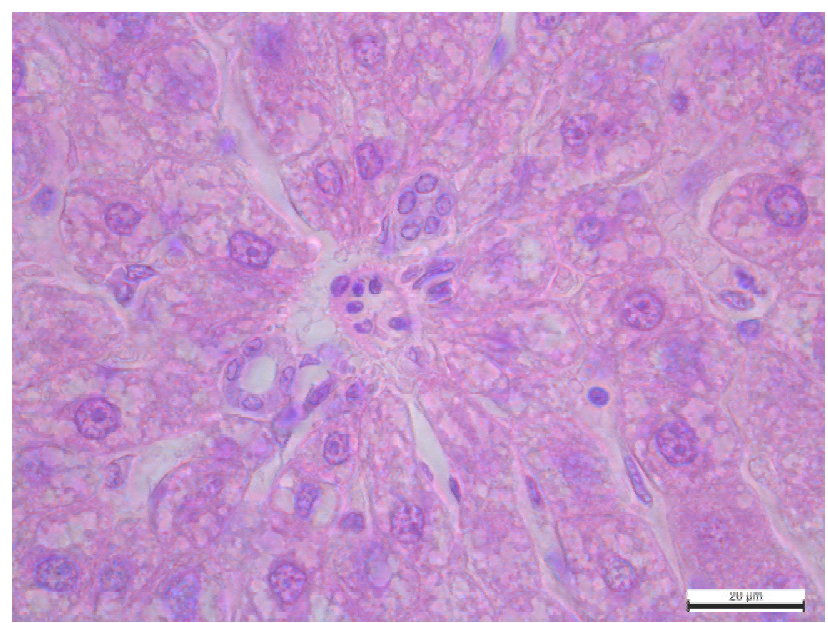

Fig. 1. A fragment of the liver with the interlobular bile duct of a control white rat after 2 weeks of the experiment. Staining with hematoxylin and eosin. Photomicrograph. x1000.

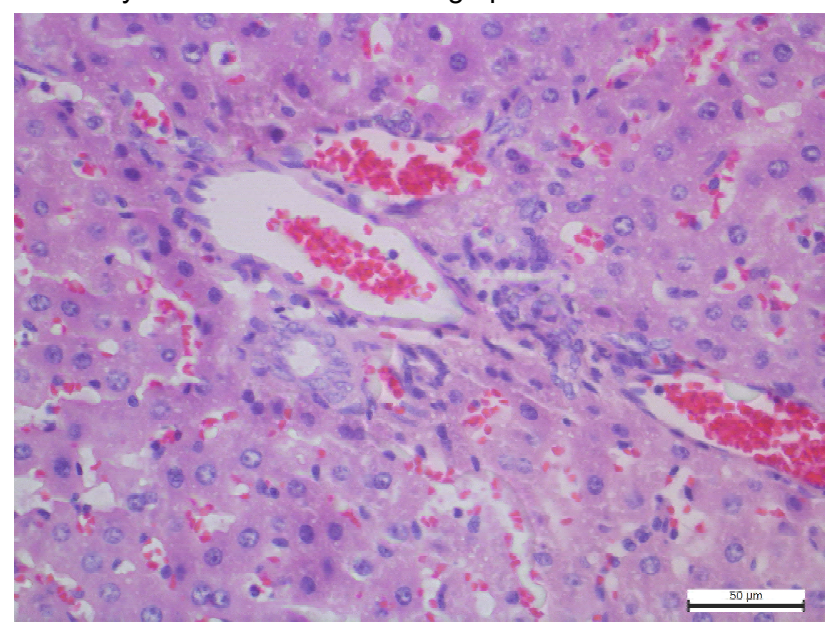

Fig. 2. Fragment of the liver of a white rat with dilated, hyperemic interlobular vessels, interlobular bile duct with two rows of cholangiocytes after 2 weeks of nalbuphine administration. Staining with hematoxylin and eosin. Photomicrograph. x400.

that the wall thickness of the interlobular bile duct was $2,672 \pm 0.414 \mu \mathrm{m}$, the diameter of the lumen of the interlobular bile duct $-5.334 \pm 0.290 \mu \mathrm{m}$. However, already at this time of the experiment the interlobular vessels are dilated, fullblooded, their walls are thinned, single interlobular bile ducts with replacement of monolayer epithelium by bilayer, loss of clear contours of the lumen and its own plate (Fig. 2).

After 4 weeks of experimental exposure to nalbuphine, noted signs of inflammation of the interlobular bile ducts, deformation and expansion of the lumen of the interlobular bile ducts, their diameter was $11.13 \pm 0.91 \mu \mathrm{m}$, and their wall thickening to $5.474 \pm 0.361 \mu \mathrm{m}$ was noted against the background of liver particle destruction. Cholangiocytes are often without clear contours, their nuclei are large, deformed, swollen, observed protrusions of the epithelium into the lumen of the ducts. The own plate of interlobular bile ducts is swollen, fluffy, in some places stratified. In the lumens of the interlobular bile ducts - stagnation of secretion. The portal 


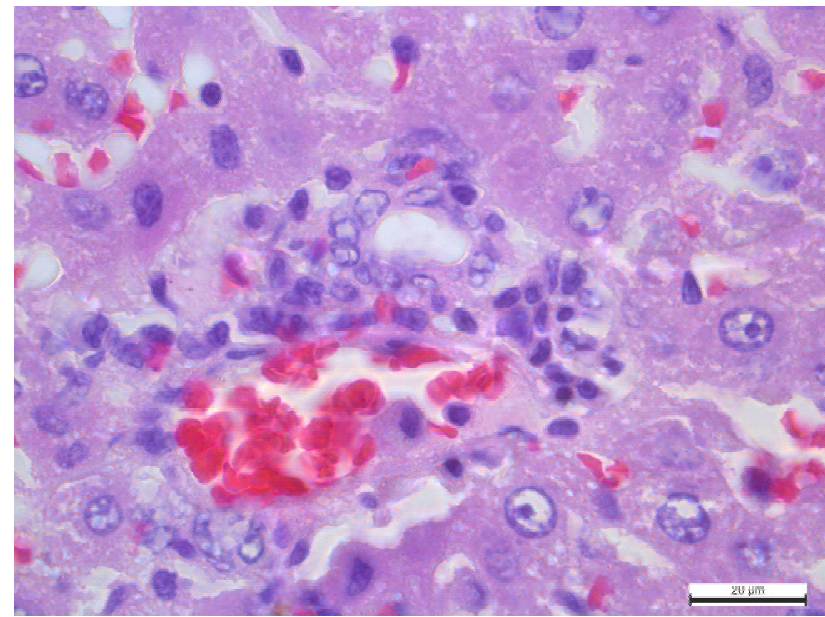

Fig. 3. Fragment of the liver of a white rat with an interlobular bile duct and an interlobular vein after 4 weeks of nalbuphine administration. Staining with hematoxylin and eosin. Photomicrograph. x1000.

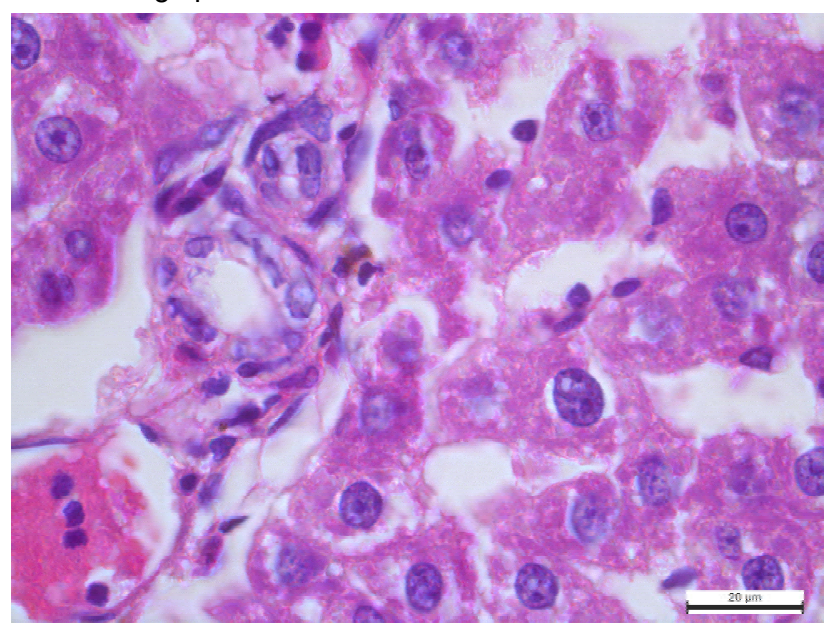

Fig. 4. Fragment of the liver (in a state of vacuolar dystrophy) of a white rat with an interlobular bile duct and an interlobular vein after 4 weeks of nalbuphine administration. Staining with hematoxylin and eosin. Photomicrograph. x1000.

tracts are dilated due to edema of the stroma (Fig. 3).

The lumens of the portal vessels are dilated, filled with blood cells, endotheliocytes are swollen, unevenly distributed on the inner surface of the vessels, in single vessels revealed desquamation of the endothelium into the lumen of the vessel, perivascular lymphocytic infiltration.

After 6 weeks of the experiment, the interlobular bile ducts were destructured, their lumens were uneven, lost their regular shape, mostly dilated, their diameter increased to $18.22 \pm 4.34 \mu \mathrm{m}$, filled with contents (detritus from a mixture of bile, mucus, remnants of exfoliated cholangiocytes). The walls of the interlobular bile ducts are deformed, their thickness increased to $6.662 \pm 1.123 \mu \mathrm{m}$. The cell layer of the ducts is disorganized, in some places the epithelial layer is thinned due to detachment of cholangiocytes, cholangiocytes acquire a flattened shape, polymorphism of their nuclei is noted, the nuclei lose their location in the center of the cell. The own plate of the wall of the interlobular ducts is stratified, intermittent, fragmented (Fig. 4).

During this period of the experiment, periductal edema, dilatation of the interlobular portal tracts due to increased edema, portal fibrosis, "varicose" veins of the interlobular portal tracts, pronounced smooth muscle hyperplasia of the interlobular arteries, artery wall thickened due to plasma accumulation were observed. In the vessels of the interlobular portal tracts, the phenomena of productive vasculitis with obliteration of the lumen, blood separation, leukostasis and leukodiapedesis in the venous component of the bloodstream, which is a sign of inflammation, perivascular - lymphocytic infiltrates were detected.

\section{Discussion}

The high incidence of diseases of the hepatobiliary system associated with drug abuse is an urgent and important problem today for both morphologists and practitioners of gastroenterology and surgery [19]. Many issues of this problem still remain unresolved and need to be supplemented and clarified. That is why there is a need for theoretical knowledge about the structural changes of the bile ducts under the influence of opioids.

The results of our morphological study of the interlobular bile ducts of white laboratory rats under conditions of six weeks of exposure to nalbuphine showed, first of all, in the interlobular portal tracts periductal vascular response, characteristic for other organs with long-term administration of opioids to experimental animals [21]. Already in the early stages of the experiment (2-4 weeks) the vessels of the portal tracts were significantly dilated, full-blooded (the lumen of the vessels is filled with erythrocytes). Circulatory disorders led to the development of perivascular edema, which in combination with lymphocytic and histiocytic infiltration spread along the stroma. Changes in the structural organization of the interlobular bile ducts, which we observed during 6 weeks of the experiment, fit into the picture of cholangitis, when there is desquamation of the epithelium of the interlobular bile duct, dilatation of the ducts, diffuse inflammatory infiltrate around the ducts, edema of the portal tract and atrophic changes of cholangiocytes (stage I and II cholangitis), as well as ductal reaction (flattening of the epithelial cells of the mucous membrane of the bile ducts), which is characteristic of the stage of progression (stage III) [8]. Type II proliferation occurs when the intrahepatic ducts proliferate (spread) to the periportal areas [9]. An increase in the diameter of the cross section of the interlobular ducts is a diagnostic sign of damage, obstruction of the biliary tree [26]. Compensatory processes include the proliferation of cholangiocytes, which causes corrugation of the inner surface of the duct wall, which leads to an increase in its surface area by 2 or more times [26]. We observed a violation of the beam organization of hepatocytes, which may be due to the fact that intrahepatic bile ducts are involved in modulating fluidity and alkalinity due to electrolyte secretion, osmotic gradients increase bile flow by inducing secondary 
water secretion, cholangiocytes play an important role in acidic acid and bile acid metabolism, dysfunction of the intrahepatic bile ducts causes a violation of the metabolism of toxic bile acids and leads to intrahepatic accumulation of bile acids [11]. The results of our study are consistent with isolated data from the professional literature on the rapidly progressive destruction of the intrahepatic bile ducts associated with the use of narcotic drugs.

The data of the study can be used in practical medicine in the diagnosis and treatment of pathological conditions of the interlobular bile ducts due to long-term use of opioids.

\section{Conclusions}

The first signs of violation of the microstructure of the interlobular bile ducts are visible after 2 weeks of

\section{References}

[1] Al-Nowfal, A., \& Al-Abed, Y. A. (2016). Chronic biliary colic associated with ketamine abuse. International medical case reports journal, 9, 135-137. doi: 10.2147/IMCRJ.S100648

[2] Baumeister, D., Tojo, L. M., \& Tracy, D. K. (2015). Legal highs: staying on top of the flood of novel psychoactive substances. Therapeutic advances in psychopharmacology, 5(2), 97-132. doi: $10.1177 / 2045125314559539$

[3] Bulhakov, S. A. (2015). Opiate receptor agonists in gastroenterological practice. Evidence-Based Gastroenterology, 4(1), 14-18.

[4] De Angelis, C., Marietti, M., Bruno, M., Pellicano, R., \& Rizzetto, M. (2015). Endoscopic ultrasound in common bile duct dilatation with normal liver enzymes. World journal of gastrointestinal endoscopy, 7(8), 799-805. doi: 10.4253/wjge.v7.i8.799

[5] Drahulian, M. V., Hulko, T. P., Kordium, V. A., Bubnov, R. V., \& Deriabina, O. G. (2014). Simulation of toxic liver damage in a mouse line ICR. ScienceRise, 4(1(4)), 13-20.

[6] Farnia, M. R., Babaei, R., Shirani, F., Momeni, M., Hajimaghsoudi, M., Vahidi, E., \& Saeedi, M. (2016). Analgesic effect of paracetamol combined with low-dose morphine versus morphine alone on patients with biliary colic: Adouble blind, randomized controlled trial. World journal of emergency medicine, 7(1), 25-29. doi: 10.5847/wjem.j.19208642.2016.01.004

[7] Fenner, E. K., Boguniewicz, J., Tucker, R. M., Sokol, R. J., \& Mack, C. L. (2014). High-dose lgG therapy mitigates bile ducttargeted inflammation and obstruction in a mouse model of biliary atresia. Pediatric research, 76(1), 72-80. doi: 10.1038/ pr.2014.46

[8] Fickert, P., Pollheimer, M. J., Beuers, U., Lackner, C., Hirschfield, G., Housset, C., ... \& Melum, E. (2014). Characterization of animal models for primary sclerosing cholangitis (PSC). Journal of hepatology, 60(6), 1290-1303. doi: 10.1016/ j.jhep.2014.02.006

[9] Franchitto, A., Onori, P., Renzi, A., Carpino, G., Mancinelli, R., Alvaro, D., \& Gaudio, E. (2013). Recent advances on the mechanisms regulating cholangiocyte proliferation and the significance of the neuroendocrine regulation of cholangiocyte pathophysiology. Annals of translational medicine, 1(3), 27. doi: 10.3978/j.issn.2305-5839.2012.10.03

[10] Giusto, M., Barberi, L., Di Sario, F., Rizzuto, E., Nicoletti, C., Ascenzi, F., ... \& Musaró, A. (2017). Skeletal muscle myopenia in mice model of bile duct ligation and carbon tetrachloride induced liver cirrhosis. Physiological reports, 5(7), e13153. administration of nalbuphine to white rats. During the next 4 weeks during the experiment pathological changes increase and are manifested by destructuring of the interlobular bile ducts, loss of proper shape, expansion and unevenness of their lumens, deformation and thickening of the walls of the interlobular bile ducts, the thickness of which increased by 2-3 times, disorganization of cholangiocytes, thinning of the cell layer due to detachment of cholangiocytes, polymorphism of their nuclei, stratification, fragmentation of the lamina propria of the interlobular bile ducts, periductal edema, dilatation of interlobular portal tracts, "varicose" of veins of the interlobular portal tracts, pronounced smooth muscle hyperplasia of the interlobular arteries, the presence of perivascular lymphocytic infiltrates.

doi: 10.14814/phy2.13153

[11] Hatano, R., Akiyama, K., Tamura, A., Hosogi, S., Marunaka, Y., Caplan, M. J., ... \& Asano, S. (2015). Knockdown of ezrin causes intrahepatic cholestasis by the dysregulation of bile fluidity in the bile duct epithelium in mice. Hepatology, 61(5), 1660-1671. doi: 10.1002/hep.27565

[12] Hresko, N. I. (2016). Structural reorganization of the colon wall under the influence of external and internal factors. Bulletin of problems of biology and medicine, 2(2), 58-61.

[13] Hrytsko, R. Yu., Zadorozhnyi, A. M., Herasun, O. B., Piniazhko, O. R., Ivankiv, O. L., Orfin, A. Ya., ... \& Myronenko, S. I. (2014). Hepatotoxicity of drugs. Hepatology, (2), 17-28.

[14] Huberhrits, N. B., Fomenko, P. G., Holubova, O. O., \& Bieliaieva, N. V. (2016). Rational choice of proton pump inhibitor for the treatment of chronic pancreatitis in combination with druginduced liver damage. Part 1. Baseline of the pancreas and liver, metabolic homeostasis. Quality of life of patients with combined pathology. Modern gastroenterology, (1), 63-81.

[15] Kartifuzova, Zh. V., Reshetnik, Ye. M., Bondzyk, O. V., Veselskyi, S. P., \& Makarchuk, M. Yu. (2008). Effect of opioid peptides on cholera in rats with subacute alcoholic liver disease. Physics of the living, 16(1), 120-127.

[16] Kartifuzova, Zh. V., Reshetnik, Ye. M., Pustovalov, A. S., Dolhova, O. M., \& Makarchuk, M. Yu. (2009). Influence of enkephalins under conditions of subacute alcoholic liver disease on morphometric parameters of its tissue and on the activity of serum enzymes. Achievements of clinical and experimental medicine, (2), 58-61.

[17] Kim, H. Y., Yang, H. K., Kim, S. H., \& Park, J. H. (2014). Ibuprofen associated acute vanishing bile duct syndrome and toxic epidermal necrolysis in an infant. Yonsei medical journal, 55(3), 834-837. doi: 10.3349/ymj.2014.55.3.834

[18] Lohash, M. V. (2016). Pathomorphological changes of rat liver under the influence of opioid at the microstructural level. Bulletin of problems of biology and medicine, 2(2), 177-184.

[19] Miethke, A. G., Zhang, W., Simmons, J., Taylor, A., Shi, T., Shanmukhappa, S. K., ... \& Nkinin, S. (2016). Pharmacological inhibition of ASBT changes bile composition and blocks progression of sclerosing cholangitis in $\mathrm{mdr} 2$ knockout mice. Hepatology (Baltimore, Md.), 63(2), 512-523. doi: 10.1002/ hep.27973

[20] Patent, Ukraine (2012). № 76564U Method for modeling physical opioid dependence in rats. Onysko P. M., Paltov E. V., Fik V. B., Vilkhova I. V., Kryvko Yu. Ya., Yakymiv N. Ya., Fitkalo O. S., 
publ. 1.

[21] Pidvalna, U., Kost, A., \& Mateshuk-Vatseba, L. (2018). Effect of Narcotic Analgesics on the Ultrastructure of the Eyeball (Experimental Study). Journal of Morphological Sciences, 35(04), 251-254. http://dx.doi.org/10.1055/s-0038-1676543

[22] Sheen, J. M., Chen, Y. C., Tain, Y. L., \& Huang, L. T. (2014). Increased circulatory asymmetric dimethylarginine and multiple organ failure: bile duct ligation in rat as a model. International journal of molecular sciences, 15(3), 3989-4006. doi: 10.3390/ ijms15033989

[23] Soleimanpour, H., Safari, S., Nia, K. S., Sanaie, S., \& Alavian, S. M. (2016). Opioid drugs in patients with liver disease: a systematic review. Hepatitis monthly, 16(4), e32636. doi: 10.5812/hepatmon.32636

[24] Sundaram, V., \& Björnsson, E. S. (2017). Drug-induced cholestasis. Hepatology communications, 1(8), 726-735. doi: 10.1002/hep4.1088

[25] Tkach, S. M. (2015). Modern approaches to the treatment of pain of biliary and pancreatic genesis. News of medicine and pharmacy, (Gastr_4), 11-17.

[26] Vartak, N., Damle-Vartak, A., Richter, B., Dirsch, O., Dahmen, U., Hammad, S., \& Hengstler, J. G. (2016). Cholestasis-induced adaptive remodeling of interlobular bile ducts. Hepatology, 63(3), 951-964. doi: 10.1002/hep.28373

[27] Zhang, Z., Li, Z., Zou, C., Zhang, J., Zhu, Y., \& Miao, Y. (2015). Angiogenesis and proliferation of bile duct enhances ischemic tolerance in rats with cirrhosis. International journal of clinical and experimental medicine, 8(8), 12086-12095. PMID: 26550120

[28] Zhuravlova, L. V., \& Shekhovtsova, Yu. O. (2018). Druginduced liver damage: tactics of diagnosis and treatment. Modern gastroenterology, 1(99), 47-52.

\section{ОСОБЛИВОСТІ СТРУКТУРНОЇ ОРГАНІЗАЦІЇ МІЖЧАСТОЧКОВИХ ЖОВЧНИХ ПРОТОК ЗА УМОВ ТРИВАЛОГО ВПЛИВУ ОПІОїДУ В ЕКСПЕРИМЕНТІ}

Матешук-Вацеба Л. Р., Гірняк I. I.

Стаття містить нові відомості щодо актуальної проблеми впливу ендо- та екзопатогенних чинників на структуру органів травної системи. Мета дослідження - встановити структурні особливості міжчасточкових жовчних проток за умов шеститижневого впливу налбуфріну в експерименті. Матеріалом дослідження слугували 30 білих лабораторних щурів самців репродуктивного віку. Гістологічні зрізи печінки забарвлювали гематоксиліном та еозином за загальноприйнятою методикою. Для фотографування мікропрепаратів використовували комп'ютерну систему "Aver Меdia". Для вимірювання діаметра просвіту та товщини стінки міжчасточкової жовчної протоки застосовували комп'ютерну програму ІтаяеЈ. Для cmamuстичного опрацювання отриманих цифрових даних використовували програмне забезпечення "Exсеl" та "Statistica" 6.0. Результати дослідження свідчать, що на тлі введення налбуфіну впродовж шести тижнів відбуваються морфологічні зміни міжчасточкових жовчних проток експериментальних тварин, що проявлялися деструктуризацією міжчасточкових жовчних проток, втратою їхньої правильної форми, розширенням та нерівномірністю їхніх просвітів, деформацією та потовщенням стінок міжчасточкових жовчних проток, товщина яких зростала у 2-3 рази, дезорганізацією холангіоцитів, стоншенням клітинного пласту внаслідок відшарування холангіоцитів, поліморфізмом їхніх ядер, розшаруванням, фрагментованістю власної пластинки стінки міжчасточкових жовчних проток, навколопротоковим набряком, розширенням міжчасточкових портальних трактів, "варикозним" розширенням вен міжчасточкових портальних трактів, виразною гладком'язовою гіперплазією міжчасточкових артерій, наявністю периваскулярних лімфоцитарних інфільтратів. Дані проведеного дослідження можуть бути використані у практичній медицині при діагностиці та лікуванні патологї жовчних проток, зумовленої тривалим застосуванням опіоїдів.

Ключові слова: міжчасточкові жовчні протоки, мікроструктура, опіоїд, експеримент.

\section{ОСОБЕННОСТИ СТРУКТУРНОЙ ОРГАНИЗАЦИИ МЕЖДОЛЬКОВЫХ ЖЕЛЧНЫХ ПРОТОКОВ В УСЛОВИЯХ ДЛИТЕЛЬНОГО ВОЗДЕЙСТВИЯ ОПИОИДА В ЭКСПЕРИМЕНТЕ \\ Матешук-Вацеба Л. Р., Гирняк И. И.}

Статья содержит новые сведения, касающиеся актуальной проблемы влияния эндо- и экзопатогенных фракторов на структуру органов пищеварительной системы. Цель исследования - определить структурные особенности междольковых желчных протоков в условиях шестинедельного влияния налбуфина в эксперименте. Материалом исследования послужили 30 белых лабораторных крыс самцов репродуктивного возраста. Гистологические срезы печени окрашивали гематоксилином и эозином по общепринятой методике. Для фотографирования микропрепаратов использовали компьютерную систему "Aver Media". Для измерения диаметра просвета и толщины стенки междолькового желчного протока применяли компьютерную программу ImageJ. Для статистической обработки полученных цифрровых данных использовали программное обеспечение "Excel" и "Statistica" 6.0. Результаты исследования свидетельствуют, что на фроне введения налбуфина в течение шести недель происходят морфологические изменения междольковых желчных протоков экспериментальных животных, которые проявляются деструктуризацией междольковых желчных протоков, потерей ими правильной фрормы, расширением и неравномерностью их просветов, деформацией и утолщением стенок междольковых желчных протоков, толщина которых возрастала в 2-3 раза, дезорганизацией холангиоцитов, истончением клеточного слоя в результате отслоения холанаиоцитов, полиморфизмом их ядер, расслоением, фррагментацией собственной пластинки стенки междольковых желчных протоков, околопротоковым отеком, расширением междольковых портальных трактов, "варикозным" расширением вен междольковых портальных трактов, выраженной гладкомышечной гиперплазией междольковых артерий, присутствием периваскулярных лимфоцитарных инфильтратов. Результаты проведенного исследования могут быть использованы в практической медицине при диагностике и лечении патологии желчных протоков, обусловленной длительным применением опиоидов.

Ключевые слова: междольковые желчные протоки, микроструктура, опиоид, эксперимент. 